\title{
Model of Sustainability Business Cattle-Ruminant Slaughterhouse Support Food Sovereignty and Toward Industrial Revolution 4.0
}

\author{
Maya Dewi Dyah Maharani ${ }^{1}$ \\ \{mayasudarsono@gmail.com ${ }^{1}$ \} \\ ${ }^{1} \mathrm{PhD}$ Environmental Engineering, Universitas Sahid Jakarta, Jl. Prof. Dr. Supomo, SH No. 84 Tebet, \\ Jakarta Selatan 12870, Indonesia
}

\begin{abstract}
This paper aims to formulate model of sustainability business Cattle Ruminant-Slaughterhouse (CR-S) support food sovereignty and toward the industrial revolution 4.0. The methods used are Multi Dimensional Scaling (MDS) analysis followed by Interpretive Structural Modeling (ISM). MDS analysis was conducted to analyze the business sustainability index business industry CR-S, while the ISM to describe the structure of the business program C R-S. Found institutional elements of the Food Agency Innovation Business as the Manager in the C R-S because it has thrust high and low dependency against the goal of the program, the public sector was affected, benchmarks to assess each goal, the needs of the program, activities required to the Planning Act, a measure of activity in order to evaluate the results achieved by each activity, the main constraints, as well as the possible change.
\end{abstract}

Keywords: sustainability, slaughterhouse, MDS, ISM.

\section{Introduction}

Indonesia government has a strong commitment to achieving the goal in the Sustainable Development Goals (SDGs), i.e. ending hunger, achieve food security and nutrition improvement, as well as promote agriculture sustainable. Local authorities fully responsible for providing basic services provision of meat and the business that are Safe, Healthy, Whole, and Halal.

Based on the Central Bureau of Statistics [1] reported total agricultural exports increased by $24 \%$ in the year 2016 until 2017 . However Indonesia food needs for imported agricultural commodities also increased, the seven main commodities of 21.70 million tons in 2014 rose to 25.50 million tons in 2017. Program of food sovereignty is the activities that must be done by the Government, with the support of private and public. The functions of C R-S in order to improve the business meat and will be to increase its protein source. The objective of the Program that the country has to and can produce food (meat) as much as needed. One of the efforts of the country to produce meat is through a strategy of food sovereignty (meat) on an ongoing basis based on a business model sustainable of CR-S.

\section{Program of Food Sovereignty}

Program of food sovereignty is the activities that desperately needed by the Government, both central, regional and provincial planning to action, with the support of private and public, 
that the functions of C R-S in order to improve the business meat, will increase its protein source and can eventually enlightened nation of Indonesia. Food sovereignty program protecting farmers, anranchers, and farmers against fish international trade justice. The activity of importing agricultural commodities in bulk almost always detrimental to farmers, and ranchers. The objective of the Program means a country can produce food as much as needed.

\section{Method}

This study was carried out in January to June 2017 is a development of previous research in the year 2014, in the city and district of Bogor, Surabaya and Malang, Semarang, Yogyakarta, and Kudus. As for the data and information obtained from the facts in the field, and the results of reports on the Performance of Government Agencies, as well as Document The Planning Medium-Term Regional Development Plan period 2015-2019. The method of data processing used is Multi-Dimensional Scaling (MDS), leverage analysis, Monte Carlo, followed by Interpretive Structural Modeling (ISM) through expert surveys in-depth interview and the opinions of various interdisciplinary comprising of bureaucrats, academics, practitioners and private sector [2].

\section{a. Multi Dimensional Scaling (MDS) Analysis}

MDS is a perceptual mapping that relies on the Euclidian Distance $\left(\mathrm{d}_{1,2}\right)$ between one dimension with dimension to another. In the MDS attributes $\left(\mathrm{d}_{1,2}\right)$ where objects are perceived has the same characteristics. The objects with different characteristics called dissimilarities so differences are both measured in distance perception which is translated in the index of perception as an index of sustainability. Determination technique based on distance $\left(\mathrm{d}_{1,2}\right)$ with the following formula:

$$
d_{1,2}=\sqrt{\left(X_{1}-X_{2}\right)^{2}+\left(Y_{1}-Y_{2}\right)^{2}+\left(Z_{1}-Z_{2}\right)^{2}+\ldots}
$$

Description:

$$
\begin{array}{ll}
\mathrm{d}_{1,2} & =\text { euclidian distance } \\
\mathrm{X}, \mathrm{Y}, \mathrm{Z} & =\text { attribute } \\
& =\text { observation }
\end{array}
$$

Euclidian distance between the two points $\left(d_{1,2}\right)$ then in the MDS is projected into two dimensions euclidian distance $\left(\dot{\mathrm{D}}_{1,2}\right)$ based on the regression formula in the following equation: $\mathrm{D}_{1,2}=\mathrm{a}+\mathrm{b} \mathrm{D}_{1,2}+\mathrm{c}$

\section{Description:}

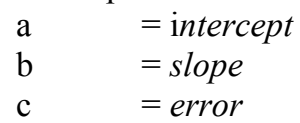

RAP-SlaughterhouseBusiness in principle makes the regression process iterations such that it the value of e the smallest and the equations equal to $0(\mathrm{a}=0)$. Iteration stops if stress $<$ 0.25 . To attribute as much as $m$ then the stress can be formulated in the following equation:

$$
\text { stress }=\sqrt{\frac{1}{m} \sum_{k=1}^{m}\left(\frac{\sum_{i} \sum_{j}\left(D_{i j k}^{2}-d_{i j k}^{2}\right)^{2}}{\sum_{i} \sum_{j} d_{i j k}^{2}}\right)}
$$


Through the method of rotation, then the position of the point of sustainability can be visualized through the horizontal and vertical axes with the sustainability index value is given a score of 0 percent (bad) and 100 percent (good). If the system has examined the sustainability index value greater than or equal to 50 percent, then the system is said to be sustainable (sustainable), and unsustainable if the index value is less than 50 percent.

\section{b. Analysis of the Leverage}

Leverage Analytics to know stability if one attribute is omitted when performed the ordination. Leverage analysis results show the percent change of the Root Mean Square (RMS) of each attribute [6].

\section{c. Analysis of Monte Carlo}

To evaluate the influence of error in the prediction value of ordination analysis used Monte Carlo statistical simulation methods, i.e., to evaluate the effect of random error in the process of prediction, as well as to evaluate the actual values. The output of the analysis of the Rap-SlaughterhouseBusiness is an index of sustainability from 0-100 shown in the indicators of ordination and leveraging. Sustainability indices are grouped in four categories, namely: 0.00-25.00 (unsustainable); 25,01-50.00 (less sustainable); 50.01-75.00 (sustainable enough); 75,01-100.00 (sustainable).

\section{d. Interpretive Structural Modeling (ISM)}

Method of Interpretive Structural Modeling (ISM) had the ability to output the analyzed subject effectively and produce decisions of structuring the program better. ISM is also a methodology that is well constructed to identify and summarize the relationships between interrelated subject specific problems or issues [7]. ISM is group learning process, structural models where produced in order to photograph the subject complex of a system, through a carefully designed pattern by using the graphics and the sentence. The technique is intended for studies by the ISM system, but can also be used by a researcher.

The technique of ISM with relevant interpretation of an object, or a representative of the system through the application of graphic theory in a systematic and iterative [8]. ISM is the process of transforming mental models that are not the light and weak explanation be a model system that looks as well as clearly defined and useful for a variety of purposes. However the technique is systematic analysis of the ISM from a program providing valuable value for society in meeting the needs of the present nor the future. Methodology and techniques of ISM is divided into two parts, namely the preparation of the hierarchy and classification subelements. The basic principle is the identification of the structure within a system that delivers high-value benefits to the system effectively and prepare for better decision making.

Based on [8,9] program can be divided into nine elements, namely: (1) sectors of society are affected, (2) the needs of the program, (3) the major constraints, (4) changes are possible, (5) the purpose of the program, (6) benchmarks to assess each the goal, (7) the activity is required to the Planning Act, (8) the size of the activity in order to evaluate the results achieved by each activity, and (9) institutions involved in the implementation of the program. Refer to the concept formulation CR-S business on an ongoing basis to support food sovereignty through a program of food sovereignty (meat) are effective in the study currently prioritizing on two elements, namely the objective of the program, and involved in the program. This was confirmed with the existing condition that administrative functions between 3 (three) involved in institutional affairs of food sovereignty in Indonesia is not yet optimal. The Ministry of Agriculture of the Republic of Indonesia has the authority in terms of 
the supervision of the production of crops, livestock, and fish, while food commodity price control authority is exercised by the Ministry of Trade of the Republic of Indonesia. The stock farm commodities authority is exercised by the State logistics.

Three things that are generated by the ISM methods include: (1) a key element, (2) the structure of the hierarchy of elements, and (3) grouping elements in the four sectors classification. With regard to the classification of sectors is four I or II or sector independent, linkage, sector III or IV of the sector, and the dependent or autonomous. Independent sector classification is the element that has the power of a great mover, and a small dependency. Classification of the sector is a sector that has linkage relationships between variables that are not stable and any changes to the variables of the action will affect other sub-elements.

The classification of sectors is sub-dependent elements which are not free. The classification of sectors is an autonomus, sub-elements that are not directly related to the system, have a relationship that is a bit more powerful, but can be influential terrhadap achievement of goals.

\section{Results and Discussion}

Validation of simulated results of Rap-SlaughterhouseBusiness for the third dimension can be seen in table 1 , indicated by the value of the coefficient of determination $\left(R_{2}\right)$ is high enough $(>0.90)$. This value means that the attributes that are included have a big enough role in explaining the diversity of the third-dimensional model was built. The magnitude of the value $\mathrm{S}$ of the third dimension dimension stress can represent a model that was rated good.

Table 1. Data calculation result value of $\mathrm{R}^{2}$, stress value, MDS analysis and Monte Carlo

\begin{tabular}{llllll}
\hline Dimensions & $\mathrm{R}^{2}$ & Stress value & MDS result & Monte Carlo result & Difference \\
\hline Ecology & 0,950 & 0,213 & 53,110 & 52,745 & 0,365 \\
Economy & 0,954 & 0,218 & 54,172 & 54,115 & 0,057 \\
Social & 0,958 & 0,212 & 54,618 & 54,486 & 0,132
\end{tabular}

The small difference in the results of the counting of the MDS analysis of Monte Carlo for the third dimension shows the results of the counting of the results of the MDS can reflect the actual value with accuracy (precision). Evaluation of the influence of random errors (error) is performed using Monte Carlo analysis which aims to find out (1) influence of manufacturing errors attribute score, (2) the influence of variation of allotment of scores, (3) the stability of the MDS analysis process over and over again (4) the income or loss of data errors (missing data), and (5) the value of the stress. Test the pairwise comparison of valuation experts (the expert judgement), yielding a weighted score as presented in table 2 .

Table 2. Multi-dimensional sustainability index value

\begin{tabular}{|c|c|c|c|}
\hline Dimensions & $\begin{array}{l}\text { Dimensional weight } \\
(\%)\end{array}$ & Indekx value & $\begin{array}{l}\text { The value of the index } \\
\text { weighting of result }\end{array}$ \\
\hline Ecology & $55,00 \%$ & 53,11 & 29,21 \\
\hline Economy & $20,00 \%$ & 54,17 & 10,83 \\
\hline Social & $25,00 \%$ & 54,62 & 13,66 \\
\hline The total number of & $100,00 \%$ & & 54,00 \\
\hline
\end{tabular}

Table 2 shows that the value of the weighted index multi-dimensional sustainability MDS of 54.00 meaning are sustainable enough. Assessment of the CR-S continuously vulnerable to conflicts that will arise in the future because it is on the index approached 50.00. Subsequently 
found to leverage attributes include: (1) availability of animals cut, (2) availability of water in equitable; (3) the criteria of the construction, layout and equipment to achieve the status of hygiene and sanitation, (4) conduct business people are willing to carry out the hygiene and sanitation at the level of the scale of the business venture, (5) communication technology based business orientation and information, and the gametrescue primarily for animals cut Indonesia's original (6) the allocation of the costs of waste management, (7) communications business experience in the past, (8) the availability of agricultural land sustainable, (9) small scale agroprocessor business growth, and (10) the conflict between business manager CR-S with service users, businessmen as well as CR-S Services between users CR-S.

To ten deserve the attribute is included in the Business strategy of the CR-S on an ongoing basis, which is program followed up with food sovereignty (meat) [9]. Further attributes the leverage the above note by Businessman CR-S on an ongoing basis, given that the State of Indonesia as an agricultural country has lost more than 600,000 hectares of farm land over the next five years, with the details of 7.10 million hectares of land in conditions of active, land ownership and the status of the majority of farmers, breeders of less than 2.00 hectares of land. The condition causes a threat to the availability of land to leverage attributes breeders animal pieces. Leverage behavioral attribute the willingness of Businessman CR-S implement the hygiene and sanitation at the level of the scale of the effort is a worthy attributes intervened, not to found the possibility of declines of public health, the safety of workers, as well as meat contamination. Increased surveillance, and targeting workers CR-S can be used to detect disease outbreaks, so beneficial for workers, businessman CR-S, as well as consumer [10]. CR-S building requirements that include construction, the layout of the main drainage of wastewater, animal welfare, and the equipment required to support the attributes and sanitary hygiene status of leverage [11]

Indigestible Foreign Bodies (IFB) which consists of a plastic bag, the seed of the fruit, fabrics, rope, hair, leather, stone, metal, wire, and nails are still found in the rumen of animals after slaughtered in CR-S is a serious problem related with information on animal health. This leads to decreased production and death in animals. Therefore, attributes of the waste drainage channels to leverage solid waste disposal worthy intervened in the business of CR-S [12].

\section{a. Purpose of the Program elements}

Purpose of program element consists of ten sub-elements, namely: (1) production meat $\left(\mathrm{G}_{1}\right)$, (2) technology of Artificial Insemination, Embryo Transfer, Information and Communication technology $\left(\mathrm{G}_{2}\right)$, (3) regulates of clean water in a fair manner $\left(\mathrm{G}_{3}\right)$, (4) improve infrastructure related technologies $\left(\mathrm{G}_{4}\right)$, (5) cooperation with the users of the CR-S $\left(\mathrm{G}_{5}\right)$, (6) cooperation with Breeders $\left(\mathrm{G}_{6}\right)$, (7) manuscript of CR-S $\left(\mathrm{G}_{7}\right)$, (8) components within the meat prices $\left(\mathrm{G}_{8}\right)$, (9) business functions of CR-S $\left(\mathrm{G}_{9}\right)$, and (10) sustainable of produce animal $\left(\mathrm{G}_{10}\right)$. Expert assessment of the relationship between contextually sub-elements goals expressed by the matrix Structural Self Interaction Matrix (SSIM) [13,14].

Contextual relationships between sub-elements purpose indicates its role supporting the program. The results indicate that the sustainability produce animals $\left(\mathrm{G}_{10}\right)$ is very supportive of the role of food sovereignty based on meat. Therefore, the element is a key element in the element of the purpose of the program.

From the classification of the purpose of the sub-elements exposed on Figure 1, identified that, sub-elements sustainability of produce animals is a sub-elements of a goal that has thrust force the success of the program. These sub-elements have little dependency toward the 
program, so that the failure of the program does not have a direct impact. Figure 1 depicts the sub-elements that production meat $\left(\mathrm{G}_{1}\right)$, technology of artificial insemination, embryo transfer, information and communication technology $\left(\mathrm{G}_{2}\right)$, improve infrastructure related technologies $\left(\mathrm{G}_{4}\right)$, cooperation with the users of the CR-S $\left(\mathrm{G}_{5}\right)$, cooperation with Breeders $\left(\mathrm{G}_{6}\right)$, as well as being able to formulate the components within the meat prices $\left(\mathrm{G}_{8}\right)$, has the relationships between variables that are unstable or included in sector linkage. Any changes to the variables of the action will affect other sub-elements.

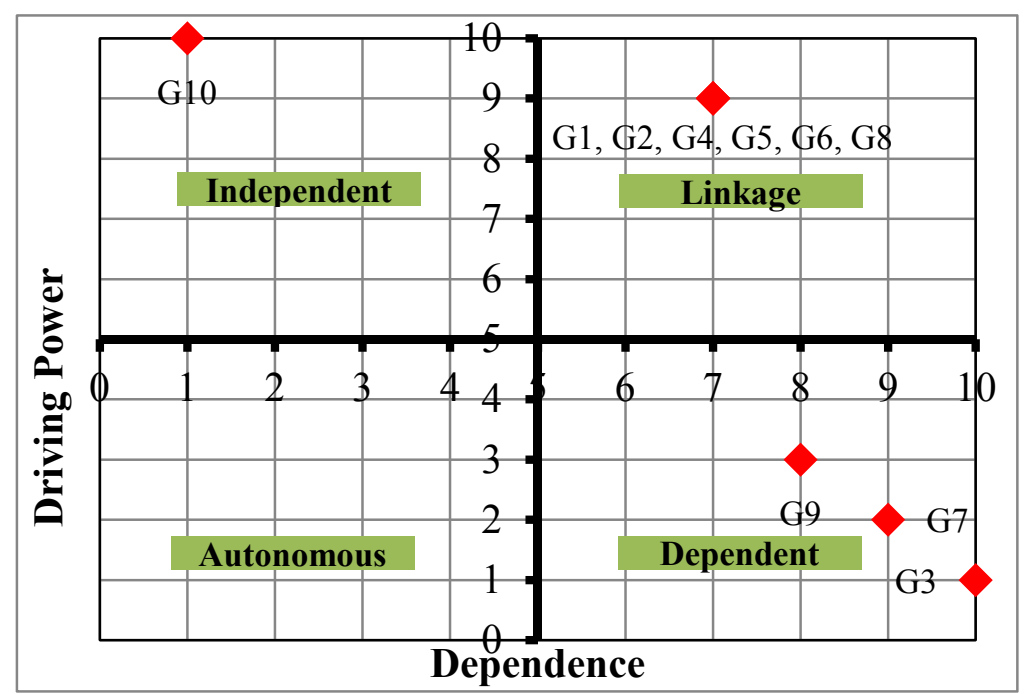

Pict 1. Driver power relations and dependence on the element of purpose to achieve food sovereignty program based on meat

Description Figure :

$\mathrm{G}_{1} \quad$ :production meat

$\mathrm{G}_{2}$ :technology of artificial insemination, embryo transfer, information and communication technology

$\mathrm{G}_{3} \quad$ :regulates of clean water in a fair manner

$\mathrm{G}_{4} \quad$ :improve infrastructure related technologies

$\mathrm{G}_{5} \quad$ :cooperation with the users of the CR-S

$\mathrm{G}_{6} \quad$ :cooperation with Breeders

$\mathrm{G}_{7}$ :manuscript of CR-S

$\mathrm{G}_{8} \quad$ :components within the meat prices

$\mathrm{G}_{9} \quad$ :business functions of CR-S

$\mathrm{G}_{10} \quad$ :sustainable of produce animal

Analysis of the classification of the elements, it also shows that there is no free variables and is affected by the existence of a program as a result of the action the purpose of other elements. Sub-elements are included in the dependent sector is business functions of CR-S $\left(\mathrm{G}_{9}\right)$, manuscript of CR-S $\left(\mathrm{G}_{7}\right)$, as well as regulates of clean water in a fair manner $\left(\mathrm{G}_{3}\right)$. To the three elements of the objectives is the independent free and not be affected by the program as a result of other purposes. Nevertheless, to the three elements have the role of supporting the goal of sustainable produce animal $\left(\mathrm{G}_{10}\right)$. Further manuscript of CR-S $\left(\mathrm{G}_{7}\right)$ causes an 
increase in the effectiveness and long-term sustainability, while increasing cooperation with the users of the CR-S $\left(\mathrm{G}_{5}\right)$ can be better. Sub elements to enhance cooperation with Breeders $\left(\mathrm{G}_{6}\right)$ support its role in sustainable of produce animal $\left(\mathrm{G}_{10}\right)$. Technology of artificial insemination, embryo transfer, information and communication technology $\left(\mathrm{G}_{2}\right)$, production meat $\left(\mathrm{G}_{1}\right)$ is slowly and gradually can be realized.

For the best goal setting through a holistic vision of food sovereignty program based on meat, i.e. sustainable of produce animals $\left(\mathrm{G}_{10}\right)$, its role is able to produce meat $\left(\mathrm{G}_{1}\right)$, Artificial Insemination, Embryo Ttransfer technology, and communication and technology information $\left(\mathrm{G}_{2}\right)$, improve infrastructure related technologies $\left(\mathrm{G}_{4}\right)$, cooperation with the users of the CR-S $\left(\mathrm{G}_{5}\right)$, increased cooperation with Breeders $\left(\mathrm{G}_{6}\right)$ as well as being able to formulate components within the meat prices $\left(\mathrm{G}_{8}\right)$. The sixth of these goals will support on the purpose of business functions of CR-S $\left(\mathrm{G}_{9}\right)$. Manuscript of $\mathrm{CR}-\mathrm{S}\left(\mathrm{G}_{7}\right)$, contributing to the management of regulates of clean water in a fair manner to facilitate the process of hygienic and sanitation on CR-S $\left(\mathrm{G}_{3}\right)$ can gradually achieved.

\section{b. The Sub Element of The Institutions Involved}

Elements of the institutions involved consists of 10 (ten) sub elements, namely: (1) the Agency's Regional Food in the form of institutional Areas owned enterprises (BUMD) ( $\left.\mathrm{L}_{1}\right)$, (2) Regional Food Agency in the form of institutional Agency Business Service area (BULD) $\left(\mathrm{L}_{2}\right)$, (3) Service Agriculture, livestock, Fisheries $\left(\mathrm{L}_{3}\right)$, (4) work Unit under the Agency's Regional Food in the form of institutional Units Implementing the technique $\left(\mathrm{L}_{4}\right)$, (5) Food Security Agency $\left(\mathrm{L}_{5}\right),(6)$ work Unit under the Department of agriculture, livestock, Fisheries areas in the the institutional form of Implementing Regional Engineering Units Slaughterhouse Animals Ruminants (UPTD-RPHR) $\left(\mathrm{L}_{6}\right)$, (7) private companies $\left(\mathrm{L}_{7}\right)$, (8) the joint between the Department of agriculture and food security $\left(\mathrm{L}_{8}\right)$, (9) State logistics in the region $\left(\mathrm{L}_{9}\right)$, as well as (10) Department of industry and trade $\left(\mathrm{L}_{10}\right)$. Contextual relationships between sub-national institutions involved elements of the program that was declared with the Self-Structural Interaction Matrix (SSIM). Contextual relations sub elements of the role involved supporting institutions towards food sovereignty program based on meat.

In accordance with the contextual relationship on this element, the result of the ISM shows that the institutions that have a role in support of the program is the Food Area in the form of institutional Agency Business Service area (BULD) $\left(\mathrm{L}_{2}\right)$ the driving power of the highest and the lowest dependency than other sub-elements, so sub-elements are key elements of the sub element of the institutions involved his role in supporting the programme of food sovereignty based meat.

Sub-elements of the institution are exposed in Figure 2 suggest that, the Agency Food Area in the form of institutional owned enterprises (BUMD) $\left(\mathrm{L}_{1}\right)$, the Agency Food Area in the form of institutional Agency Business Service (BULD $\left(\mathrm{L}_{2}\right)$, work Unit under the body of the Regional food in the form of institutional Units Implementing the technique (UPTD) ( $\mathrm{L}_{4}$ ), and private companies $\left(\mathrm{L}_{7}\right)$ based on the classification level of Dependency and Driver Power are on the independent sector. To the four sub-elements of the free variables had a great driving force of power and influence against the success of the program. In addition, three institutions, the Agency Food Area in the form of institutional Areas owned enterprises (BUMD) $\left(\mathrm{L}_{1}\right)$, work Unit under the Agency's Regional Food in the form of institutional Units Implementing the technique area (UPTD) $\left(\mathrm{L}_{4}\right)$, and private companies $\left(\mathrm{L}_{7}\right)$ support the role of the Agency in the Area of institutional forms of the food agency's Regional Business Service (BULD $\left(\mathrm{L}_{2}\right)$ which is an independent institution to evaluate the performance of the implementation of the service availability of meat. The Agency's Regional Food in the form of 
institutional Agency Business Service (BULD) as institutions that have a consensus that more is expected to maintain the sustainability of business services. Integrated supervision allows the provision of service sustainability meat the better.

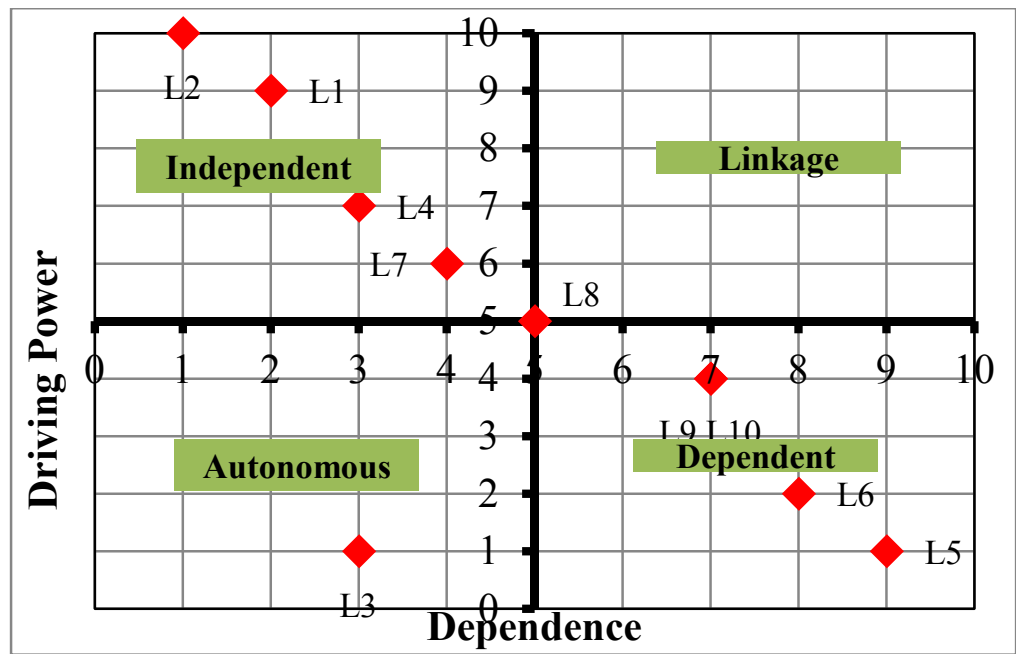

Fig. 2. Power driver Relations - dependence on elements of the institutions involved food sovereignty program based on meat

Description figure 2:

$\mathrm{L}_{1} \quad$ : Agency's Regional Food in the form of institutional Areas owned enterprises (BUMD)

$\mathrm{L}_{2}$ : Regional Food Agency in the form of institutional Agency Business Service area (BULD)

$\mathrm{L}_{3}$ : Service Agriculture, livestock, Fisheries

$\mathrm{L}_{4}$ : Work Unit under the Agency's Regional Food in the form of institutional Units Implementing the technique (UPTD)

$\mathrm{L}_{5} \quad$ : Food Security Agency

$\mathrm{L}_{6}$ : Work Unit under the Department of Agriculture, Livestock, Fisheries in the the institutional form of Implementing Regional Engineering Units RuminantSlaughterhouse (UPTD-RPHR)

$\mathrm{L}_{7} \quad$ : Private company

$\mathrm{L}_{8} \quad$ : The joint between the Department of agriculture and food security

$\mathrm{L}_{9}$ : State logistics in the region

$\mathrm{L}_{10}$ : Department of industry and trade .

The sub element is included in the free variables is the State logistics in the region $\left(\mathrm{L}_{9}\right)$, Department of industry and trade $\left(\mathrm{L}_{10}\right)$, Food Security Agency $\left(\mathrm{L}_{5}\right)$, and Work Unit under the Department of Agriculture, Livestock, Fisheries in the the institutional form of Implementing Regional Engineering Units CR-S (UPTD-RPHR) ( $\left.\mathrm{L}_{6}\right)$. All elements on this sector of the dependent role is supported by Regional Food Agency in the form of institutional Agency Business Service (BULD) $\left(\mathrm{L}_{2}\right)$. Work unit under the Department of Agriculture, Livestock, Fisheries in the form of institutional Units Implementing the technique CR-S (UPTD-RPHR) $\left(\mathrm{L}_{6}\right)$ and Office of food security $\left(\mathrm{L}_{5}\right)$ its role supporting the institutional Department of agriculture, Farms, Fisheries $\left(\mathrm{L}_{3}\right)$. For the institutions involved i.e. Department of Agriculture, 
Livestock, Fisheries $\left(\mathrm{L}_{3}\right)$ and the joint Department of Agriculture, Livestock, Fisheries and Food Security $\left(\mathrm{L}_{8}\right)$ are classified in sector autonomus, is an institution that is not directly related to system, and have little relationship.

\section{Conclusion}

Aspect indicating CR-S Business on an ongoing basis are as follows: the ecological dimension of the availability of animal pieces, the availability of clean water in justice, the status of hygiene and sanitation, as well as the availability of land for sustainable agriculture. For the economic dimension includes behavior businessman willing to implement hygiene and sanitation at the level of the scale of the business venture, business orientation-based communication technology, information, and the gametrescue primarily for animals cut Indonesia's original, the allocation of the cost of waste management, as well as growth of the Micro Small Medium Enterprises that based on meat business. The next social dimension on aspect include: business communication experience CR-S in the past, and the conflict between business manager CR-S with service users, CR-S, businessmen as well as CR-S Services between users.

Further description of the structural model of food sovereignty program description (meat) has the purpose of Producing animals cut back as raw Food of animal Origin (meat) a safe Healthy Intact Kosher. As for important institutions involved have high thrust against the success of the program is the Food in the form of institutional Agency Business Service

\section{References}

[1] [BPS] Badan Pusat Statistik. 2017. Nilai ekspor Indonesia Desember 2017 mencapai US\$14,79 miliar dan Nilai impor Indonesia Desember 2017 mencapai US\$15,06 miliar. https://www.bps.go.id/pressrelease/2018/01/15/1416

[2] Eriyatno. 2012. Ilmu sistem meningkatkan mutu dan efektivitas manajemen. 1(4): 134138

[3] Fauzi. 2012. Modelling with rapid appraisal (RAP) for sustainability assessment using Rapfish. 
[4] Maya Dewi Dyah Maharani, Sumardjo, Eriyatno, Eko Sugeng Pribadi. 2017. Management Strategy for Sustainable Ruminant-Cattle Slaughterhouse. Journal Veterinary

[5 Luh Putu Desy Puspaningrat, Eko Sugeng Pribadi, Maya Dewi Dyah Maharani. 2018. Faktor-Faktor Penentu Status Berkelanjutan Tempat Penampungan dan Potong Ayam (TPnA). [Tesis]. Bogor (ID): Institut Pertanian Bogor.

[6] Kavanagh, P, Pitcher, TJ. 2004. Implementing microsoft excel software for rapfish: a technique for the rapid appraisal of fisheries status. Fisheries Center Method. Rev. 12(2):136-140

[7] Maya Dewi Dyah Maharani, Dem Vi Sara. 2018. Model Struktural Pengelolaan Tempat Penampungan Dan Potong Ayam Secara Berkelanjutan, Dalam Mendukung Ketahanan Pangan. Peran Matematika, Sains, dan Teknologi dalam Mencapai Tujuan Pembangunan Berkelanjutan/SDGs. Universitas Terbuka: 307.1

[8] Saxena J.J.P. 1992. Hierarchy and Classification of Program Plan Elements Using Interpretive Structural Modelling. System Practice, vol 5(6), 651:670

[9] Maya Dewi Dyah Maharani, Sumardjo, Eriyatno, Eko Sugeng Pribadi. 2015. Model Pengelolaan

Unit Usaha Jasa Rumah Potong Hewan Ruminansia (RPH-R) Secara Berkelanjutan. [Disertasi]. Bogor (ID): Institut Pertanian Bogor.

[10] Elizabeth Anne Jessie Cook, William Anson de Glanville, Lian Francesca Thomas, Samuel Kariuki, Barend Mark de Clare Bronsvoort, and Eric Maurice Fèvre. 2017. Working conditions and public health risks in slaughterhouses in western Kenya. BMC Public Health. 17:14. doi: 10.1186/s12889-016-3923-y

[11] S. F. Bwatota, M. Makungu, and H. E. Nonga. 2018. Occurrences of Indigestible Foreign Bodies in Cattle Slaughtered at Morogoro Municipal Slaughterhouse, Tanzania. Hindawi Journal of Veterinary Medicine, (ID): 4818203, 6 pages https://doi.org/10.1155/2018/4818203

[12] S. F. Bwatota, M. Makungu , and H. E. Nonga. 2018. Occurrences of Indigestible Foreign Bodies in Cattle Slaughtered at Morogoro Municipal Slaughterhouse, Tanzania. Hindawi Journal of Veterinary Medicine, (ID): 4818203, 6 pages https://doi.org/10.1155/2018/4818203

[13] Dino Rimantho dan Hera Rosdiana. 2017. Penentuan Faktor Kunci Peningkatan Kualitas Air Limbah Industri Makanan Menggunakan Interpretative Structural Modeling (ISM). Jurnal Ilmu Lingkungan. Volume 15 (2): 90-95

[14] Maya Dewi Dyah Maharani, Sumardjo, Eriyatno, Eko Sugeng Pribadi. 2015. Structural Model for Sustainable Management of Ruminant-Cattle Slaughterhouse (RC-S): The Establishment and Renovation of RC-S. Journal Global Veterinaria 14(5) 